\title{
How We Approached Locally Advanced (Stomach and Gall Bladder Invasion) Right Colon Tumor with Full Laparoscopic Total Mesocolic Dissection?
}

\author{
Mide ve Safra Kesesi İnvazyonu Olan Lokal İleri Sağ Kolon Tümörüne \\ Komplet Mezokolik Diseksiyonla Yaklaşımımız
}

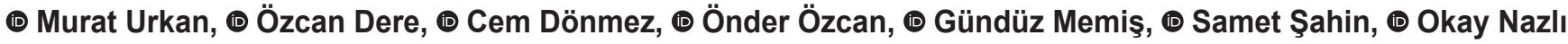 \\ Muğla Sıtkı Koçman University Training and Research Hospital, Clinic of General Surgery, Muğla, Turkey
}

\begin{abstract}
|IIIIIII| ABSTRACT
Colorectal cancer is the third most common cancer diagnosed in the word. While the incidence and the mortality rate of colorectal cancer has decreased due to effective cancer screening measures, gastric or duodenal invasion by locally advanced right colon cancer is an unusual event, the management of which represents a surgical challenge. We aim to share our experience of treating patients with locally advanced, right-sided colon cancer that directly invaded the duodenum, gastric body and gallbladder. The lesions were safely resected laparoscopically for mesocolic dissection. The treatment was curative (R0) with minimum morbidity and mortality. High ligation of blood vessels at the D3 level and complete mesocoloic excision (CME) are both critical when operating right colon cancer. This laparoscopic approach, which normally requires extreme care, became even more challenging in locally advanced tumors. This video presentation illustrates total laparoscopic right hemicolectomy with D3 lymph node dissection and CME, cholecystectomy, and gastric and duodenum wedge resection. Reconstruction was performed with a Roux-en-Y gastroenterostomy and ileotransversostomy from the region of the resection, with tissue preservation. We wanted to show how the difficulties encountered during the operation are managed, as it is not possible to predict local advanced tumor preoperatively by physical examination. In conclusion, in selected patients, advanced laparoscopic surgery with appropriately trained and experienced staff in appropriate centers may be a solution for locally advanced tumors without compromising oncological principles.
\end{abstract}

Keywords: Right hemicolectomy, complete mesocolon excision, laparoscopic, localy invasion

\section{|IIIIIII| ÖZ}

Kolorektal kanser, tüm dünyada tanı koyulan en yaygın üçüncü kanserdir. Etkili kanser tarama önlemleri sayesinde kolorektal kanserin insidansı ve mortalite oranı azalmakta iken; ancak bu süreçte tanı koyulan lokal ileri kolon kanserlerinden; sağ kolon kanseri zemininde mide veya duodenal invazyon, yönetimi cerrahi bir zorluk teşkil eden nadir bir durumdur. Bu olgu takdiminde doğrudan duodenumu, mide korpusunu ve safra kesesini invaze eden, lokal ileri sağ kolon kanseri olan hastamızı tedavi etme deneyimimizi paylaşmayı amaçladık. Lezyonlar mezokolik diseksiyon için güvenle laparoskopik olarak rezeke edildi ve tedavi, minimum morbidite ve mortalite ile küratif (R0) olarak tamamlandı. D3 seviyesinde vasküler yapıların yüksek ligasyonu ve tam mezokolik eksizyon (CME), sağ kolon kanserini ameliyat ederken kritik öneme sahiptir. Normalde hali hazırda aşırı dikkat gerektiren bu laparoskopik yaklaşım, lokal olarak ilerlemiş tümörlerde daha da zorlayıcı hale gelmektdir. Bu video sunumu, D3 lenf nodu diseksiyonu ve CME, kolesistektomi ve mide ve duodenum wedge rezeksiyonu ile total laparoskopik sağ hemikolektomiyi göstermektedir. Temiz cerrahi sınırla, rezeksiyon bölgesinden Roux-en-Y gastroenterostomi ve ileotransversostomi ile rekonstrüksiyon yapıldı. Ameliyat öncesi fizik muayene ile tahmin etmek mümkün olmadığı için ameliyat sırasında lokal ileri olduğu tespit edilen hastada karşılaşılan zorlukların nasıl yönetildiğini göstermek istedik. Sonuç olarak, seçilmiş hastalarda, uygun merkezlerde, uygun eğitimli ve deneyimli personel ile ileri laparoskopik cerrahi, lokal ileri tümörlere onkolojik prensiplerden ödün vermeden çözüm olabilir.

Anahtar Kelimeler: Sağ hemikolektomi, komplet mezokolik eksizyon, laparoskopi, lokal invazyon

Address for Correspondence/Yazışma Adresi: Murat Urkan, MD,

Muğla Sıtkı Koçman University Training and Research Hospital, Clinic of General Surgery, Muğla, Turkey

E-mail: muraturkan@gmail.com ORCID ID: orcid.org/0000-0002-3191-4724

Received/Geliş Tarihi: 03.05.2021 Accepted/Kabul Tarihi: 14.05.2021

${ }^{\oplus}$ Copyright 2021 by Turkish Society of Colon and Rectal Surgery

Turkish Journal of Colorectal Disease published by Galenos Publishing House. 


\section{Description}

Colorectal cancers continue to be an important global cause of morbidity and mortality, despite all the advances in treatment approaches. Currently, radical surgery is the only known curative treatment option. The positive effects of the Complete Mesocolic Excision (CME) with right hemicolectomy technique on survival and local recurrence rates are indisputable. ${ }^{1,2}$ Hohenberger et al. ${ }^{1}$ showed the effect of CME on 5-year survival increased from $82.1 \%$ to $89.1 \%$. Thus, high ligation of blood vessels at the D3 level and CME are two critical features of the treatment of ascendant colon cancer. ${ }^{1}$ This laparoscopic approach, which normally requires extreme care, becomes even more challenging in locally advanced tumors. ${ }^{3}$

Surgical resection of tumors without local advancement is known to result in a lower morbidity and mortality than locally advanced colon tumors. However, the benefit of extensive surgery cannot be underestimated in the case of locally advanced tumors. Extensive surgery with careful lymph node dissection (LND) based on a no-touch isolation technique remains the gold standard. ${ }^{4}$ Here, we present a 68-year-old man with a locally advanced hepatic flexure tumor. Physical examination was uninformative. Colonoscopy revealed near total obstruction at the hepatic flexure. Computed tomography showed an irregular wall at the hepatic flexure. Radiology did not suggest invasion of adjacent organs. Postoperative pathological result was pT4b pNO (0/21) MO (phaseII C, AJCC). This video presentation illustrates total laparoscopic right hemicolectomy with D3 LND and CME, cholecystectomy and gastric and duodenum wedge resection. Reconstruction was performed with a Roux-en-Y gastro-enterostomy and ileotransversostomy from the region of the resection, with tissue preservation. In this video we wanted to show how the difficulties encountered during the operation are managed, as it is not possible to predict local advanced tumor preoperatively by physical examination.
The benefit of extensive surgery is greater in the case of stage II tumors. In other word, the overall survival time of patients with these tumors is significantly higher than patients with more conservative surgery. In conclusion, in selected patients, advanced laparoscopic surgery performed by appropriately trained (e.g Lap Co training) and experienced staff in a center with sufficient patient numbers may be successful in the treatment of locally advanced tumors without compromising oncological principles.

\section{Ethics}

Informed Consent: Obtained.

Peer-review: Internally peer reviewed.

\section{Authorship Contributions}

Surgical and Medical Practices: M.U., G.M., Ö.Ö. Concept: M.U., C.D., Ö.D. Design: Ö.Ö., Ö.D., O.N. Data Collection or Processing: M.U., C.D., O.N., S.Ş. Video adition: M.U., C.D., Literature Search: Ö.D., G.M., Ö.Ö., Writing: M.U., Ö.D., Ö.Ö.

Conflict of Interest: No conflict of interest was declared by the authors.

Financial Disclosure: The authors declared that this study received no financial support.

\section{References}

1. Hohenberger W, Weber K, Matzel K, Papadopoulos T, Merkel S. Standardized surgery for colonic cancer:complte mesoclic excision and central ligation-technical notes and outcome. Colorectal Dis 2009;11:354364.

2. Bertelsen CA, Bols B, Ingeholm P, Jansen JE, Neuenschwander AU, Vilandt J. Can the quality of colonic surgery be improved by standardization of surgical technique with complete mesocolic excision? Colorectal Dis 2011;13:1123-1129.

3. Liang JT, Lai HS, Lee PH. Laparoscopic medial-to-lateral approach for the curative resection of right-sided colon cancer. Ann Surg Oncol 2007;14:1878-1879.

4. Fujita J, Uyama I, Sugioka A, Komori Y, Matsui H, Hasumi A. Laparoscopic Right Hemicolectomy with Radical Lymph Node Dissection Using the No-Touch Isolation Technique for Advanced Colon Cancer. Surg Today 2001;31:93-96

\section{Video 2.}

https://www.doi.org/10.4274/tjcd.galenos.2021.2021-5-1.video2 